\title{
Rethinking Strategic Security: Juxtaposing Kenya's Participation in Regional Security with Stability in the Horn of Africa Region
}

\author{
Abel Holla \\ Chuka University, Kenya
}

\begin{abstract}
As the region's leading influence, Kenya is among the few African countries that have enjoyed relative peace since independence. Kenya's pivotal role in the greater Horn of Africa has been instrumental in improving regional security. The nation's influence in the areas of intelligence, counterterrorism, and personal protection has immensely contributed to the war on terror through progressive defeat of prominent extremist organizations and terror groups such as the Al-Shabaab. Moreover, Kenya is the leading hub for technological advancement and innovation within the East Africa region, with a vibrant and progressive economy. With its election as a nonpermanent member of the UN Security Council, Kenya has gained enviable status among nations as an instrumental country in world politics and peace making. This status has increased the country's position as one that can influence the geopolitics and security situation in greater Horn of Africa region. Thus, Kenya's capacity to influence and enforce stability in the Horn of Africa has exponentially increased through the years. This article will examine Kenya's contribution to peace and stability in the Horn of Africa region.
\end{abstract}

\section{INTRODUCTION}

$\mathrm{T}$ he Horn of Africa describes a group of countries that share common borders on the easternmost tip of the continent, namely: Kenya, Somalia, Djibouti, Eritrea and, to some extent, Ethiopia, South Sudan and Sudan. However, it is the formative four countries that are generally regarded as the Horn of Africa (Cardoso, 2016). From the 1960s, the region has had at least one country in the internal war brought about by coups, revolutions or liberation struggles characterized by guerrilla warfare. Nonetheless, there is a steady and progressive departure from the negativity that characterized the region in the past. Djibouti has embraced democracy, and elections are regular and moderately free and fair. This democracy has given rise to Djibouti's economic progress, with its port contributing to income generation and solid economic outlook. On the other hand, Somalia started with a transitional federal system of governance that saw relative stability in the country since the 1990s (Heally, 2011). This stability has recently translated to democratic elections and the formation of the first democratically elected government in more than 30years. Eritrea has also improved its governance issues. However, the nation still grapples with several challenges that threaten it democracy.

\section{KENYA'S ROLE IN PEACEKEEPING MISSIONS}

Based on several issues, mainly its internal peace, its alignment with world powers, and democratic leadership, Kenya plays a vital role in regional geopolitics. These strides in the area of peace and politics have made Kenya emerge as a solid and influential player in the promotion of regional stability in the Horn of Africa. One notable consequence of Kenya's involvement in security issues is that the Horn of Africa countries have experienced a gradual departure from chaos and internal strife through the years (Hesse, 2016). Therefore, the role that Kenya play's in security continues to earn recognition in the Horn of Africa region.

Kenya's involvement with the affairs of individual countries, in their capacity as singular and sovereign states, and as members of regional blocs and state parties to international organizations, stems from several reasons. Principal among these is the need for African countries to be at the forefront in encouraging the development and growth of African regional blocs to tackle any emerging peace and security issues (Cardoso, 2016).

For a country to realize this goal, it needs to achieve certain conditions; milestones that Kenya has attained over the years. These are a strong nation-state, a government capable of protecting its borders and exercising control over its territory, enjoyment of monopoly in the legitimate use of force and capacity to provide security to its citizens (Heally, 2011).

In line with the Africa Union's Peace and Security Council mandate, Kenya is involved in the Horn of Africa. This involvement is based on the AU's provisions that a country may, in conjunction with others, intervene in cases where there is genocide, crimes against humanity, war crimes and other grave crimes against the civilian population (Bamidele, 2017). The AU can also authorize a nation to intervene on its behalf, constitute an intervention force, and approve the modalities needed to restore peace and security. Based on these mechanisms, Kenya has been at the forefront of its regional interventionist and peacebuilding initiatives. 


\section{THE ROLE OF KENYA IN CONFLICT RESOLUTION IN THE HORN OF AFRICA REGION}

Among the dominant roles that Kenya has played towards the realization of stability in the Horn of Africa is in humanitarian activities (Henneberg \& Stapel, 2021). Primarily, this has been in it playing host to a vast number of refugees over the years who have been fleeing political instabilities, hunger and other natural calamities. With most international humanitarian agencies headquartered in Nairobi, the country has not only gained much-needed foreign exchange. Still, it has earned the right to address itself in the region's geopolitics. In availing the much-needed place to call home albeit, Kenya has gained credence among its neighbours and internationally as a haven for a short time (Coning C. d., 2019). By 2014, Kenya was hosting over half a million refugees from Somalia who had fled internal fighting and the Al-Shabaab menace. Though the country is playing its role as a good neighbour and fulfilling its humanitarian mandate by welcoming the refugees, it also experiences other hardships. Some of the difficulties that Kenya experiences include: competition for resources with the host communities; increase in communicable diseases, including infant diseases due to non-existent immunization programs in Somalia; increase in environmental degradation due to the use of charcoal and firewood as a means of fuel by the refugee community; and pressure on the urban infrastructure due to the increase in refugees who are moving into the urban areas in search of employment and education (Hegre, Hultman, \& Nygård, 2018). These humanitarian efforts have endeared Kenya to various African countries that have in the past been affected by strife and conflicts.

The Al-Shabaab has exploited the lack of proper engagement of the youthful population in refugee camps. The Terror group is taking advantage of the despair in the camps to recruit youths into its ranks. Unemployment, illiteracy, loss of a sense of belonging, diminished social status, among others, are the leading causes of recruitment into terrorist groups like the Al-Shabaab (Jansen, 2013). By engaging in the realization of regional stability, Kenya is ensuring that the societal inequalities that would predispose youth to extremism, not only in Kenya, but also in the countries that form the Horn of Africa, are spared of the tentacles of terrorism that would pull them into that dark vortex.

\section{KENYA'S ACHIEVEMENTS IN PROMOTING PEACE AND SECURITY IN THE HORN OF AFRICA}

Post 9/11, the world has seen an increase in terrorism-related activities by terrorist groups and other sympathetic groupings. With the collapse of the government in Somalia in the 1990s, the leadership void needed to be filled. Consequently, the Union of Islamic Courts arose. They were formed to provide and administer justice due to a lack of governance systems and the prevailing chaos. Subsequently, the Al-Ittihad alIslamiya was created; a radical Islamist group later linked with the Afghanistan mujahideen and Al-Qaeda, which sought to establish an Islamic state in Somali, the Horn of Africa in general (Colonel Buluma, 2014). By 2005 the radical Islamist group had morphed into Al-Shabaab and in that year launched one of the deadliest attacks outside its borders. In April 2005, 147 people, primarily students of Garissa University College, were killed when the insurgent terrorists crossed over into Kenya for the attack. Successive attacks continued, with the 2015 Westgate shopping mall attack being among the most notable. In the latter years, the group linked itself first with $\mathrm{Al}$ Qaeda, then with ISIS, increasing its terrorist activities in the region (Jansen, 2013).

Other than terrorist attacks within Somalia and externally in Kenya and Uganda, Al-Shabaab organized and facilitated pirate attacks against international shipping vessels plying the Gulf of Aden route (Jansen, 2013). These attacks led to an increase in import costs due to increased insurance costs and the hiring of security personnel in the form of escorts. The resultant effect on economies of Africa and those of Asia that use the Indian Ocean for transport was hitherto unmitigated.

In 2011 the Kenyan government, in response to various and increased sporadic attacks in Kenya by the Al-Shabaab, launched Operation Linda Nchi, a military-led campaign into Somalia to give military and allied support to the fledgling government (Khadiagala, 2008). It aimed at helping the Somalia government take a foothold in the country as it struggled to take over a country that was considered by many to be in virtual 'state collapse.' Within a short time, support through the $\mathrm{AU}$ in AMISOM and financial aid was introduced, with the operation being taken over by the AMISOM command. In support of its neighbour, the Kenyan government continues to have a large contingent of military personnel in Somalia supporting the central government against the insurgents whose operations have been reduced. From having a stranglehold of the country from their operations from the port city of Kismayu, the Al-Shabaab is now reduced to diminishing pockets of influence with the central government and allied forces continuing with their mission to rid the country of their power. The piracy that was rampant along the Horn of Africa coast has also dissipated thanks to additional support from the European Union through Operation Atlanta by its naval forces (Ploch, Blanchard, O'Rourke, Mason, \& King, 2011). These joint efforts between Kenya and international partners have significantly reduced the threat of the Al-Shabaab.

Another benefit of Kenya's incursion into Somalia through Operation Linda Nchi is the drastic reduction in contraband goods that would get through the terrorist-held port of Kismayu. Other than goods that did not attract the requisite tax and allied inspection on quality, the port served as a conduit for smuggling small arms and light weapons into Kenya and other countries in the East Africa region. With the defeat of the Al-Shabaab, there has been a noticeable reduction in the number of illegal arms entering the East African countries (Cardoso, 2016). Therefore, Kenya's security efforts have largely controlled the illegal proliferation 
of arms and contraband goods through the country's porous borders.

\section{KENYA'S INVOLVEMENT IN PEACE INITIATIVES AS A MEMBER OF REGIONAL AND INTERNATIONAL BODIES}

Over the years, Kenya has spearheaded its role as a nation that offers reconciliatory overtones instead of the conventional militarism typical of other influential countries. These interventions have been actualized through strategies that include: engagement in the long-running Sudan conflict that saw the birth of a new nation in South Sudan; the Somalia interclan negotiations that saw the first democratic elections in more than thirty years; the peace talks in both Djibouti and Eritrea that have seen the countries avert and overcome internal conflicts (Henneberg \& Stapel, 2021). As a member state of IGAD, Kenya is mandated to eliminate threats to regional peace, cooperation and stability. In taking the mediatory route, Kenya has helped to avert internal and crossborder skirmishes and thus contributed to regional peace (Coning, 2019). These efforts have immensely contributed to the peace and stability of African countries that were afflicted by internal conflicts.

One of the most outstanding engagements by Kenya in mediation was realized in the ending of hostilities in Sudan and the consequent talks that brought about the referendum in South Sudan and the eventual secession and creation of the new republic (Wickstead, 2013). Through the chairmanship of Lt (Rtd) Lazarus Sumbeiywo, the talks culminated in a peace agreement dubbed the Machakos Protocol in July 2002. Principal among the agreements between the two sides was the 'one country, two systems; a compromise that would provide for Sharia law in the North and a secular legal system for the South. Other issues agreed upon were holding a referendum after six years, security agreements, powersharing, and wealth-sharing, primarily from crude oil.

In the Somali peace process, the centrality of Kenya in the general build-up to peace cannot be gainsaid. First, it has been involved as part of IGAD that saw the formation of the Transitional National Government (TNG) and the formation of the subsequent transitional government under Abdulqasim Salat Hassan. With the ending of the mandate of the TNG, the Kenyan government convened Somali leaders in the town of Eldoret, where the Transitional Federal Government (TFG) was formed with a parliament from members of the various clan representations. The TFG agreed to a five-year transitional government that would create a consolidation government, write a constitution, and hold democratic elections (Henneberg \& Stapel, 2021). Further to these, the Kenyan government provided the fledgling Somalia government with a base for operations with its government and parliament residing in Nairobi and other towns. It is the culmination of these initiatives that have contributed to the progressive stability of Somalia (Hesse, 2016).
Another area in which Kenya has played a pivotal role is in initiating and promoting peace-support missions (Cardoso, 2016). This process has been actualized through both the African Union and also through the United Nations. Through the African Union, Kenya has contributed the most significant contingent of troops and equipment to the African Union Mission in Somalia (UNISOM), aimed at helping the country not only gain but maintain a stronghold against insurgent AlShabaab terrorists. Even before the deployment of AMISOM, the Kenyan government had initiated counter-insurgency measures against the Al-Shabaab after several incursions into the country that saw the death and kidnapping of several people (Colonel Buluma, 2014). The success of this measure resulted in the international community heeding calls by Kenya and Uganda. They had joined after a short while for a more potent force that would ensure the defeat of the AlShabaab and other breakaway terrorist groups.

In line with the UN's 1992 Agenda for Peace, Kenya has collaborated with the UN and other bodies in the quest for regional and national peace initiatives (Heally, 2011). The resultant peace, not only within Somalia but also in the greater eastern Africa, has brought about a new political dispensation within Somalia. The neighbours are beginning to reap its benefits. These benefits are in line with an international consensus, which since 1992 has seen countries endeavour to play more significant roles in the realization and maintenance of international peace and order.

\section{CONCLUSION}

Without the robust and deliberate involvement of Kenya in matters that affect the Horn of Africa, such as terrorism, refugees, national stability and engagement in humanitarian aid, the region would be in worse shape than it is at the moment. Kenya continues to play a pivotal role in supporting refugees from warring countries and in undertaking security operations that are intended to promote regional stability.

\section{REFERENCES}

[1] Abdi, A. A. (2012). The Impact of Conflicts in the Horn of Africa. A Case Study of Kenya.

[2] Bamidele, S. (2017). Regional Approaches to Crisis Response, the African Union (AU) Intervention in African States: How Viable Is It? India Quarterly., 73(1), 114-128.

[3] Cardoso, N. C. (2016). Regional Security in the Horn of Africa: Conflicts, Agendas and Threats. Brazilian Journal of African Studies, 1(2), 131-165.

[4] Colonel Buluma, G. (2014). Al-Shabaab: The Threat to Kenya and the Horn of Africa.

[5] Coning, C. d. (2017). Peace Enforcement in Africa: Doctrinal Distinctions Between the African Union and United Nations. Contemporary Security Policy, 38(1), 145-160.

[6] Coning, C. d. (2019). Africa and UN Peace Operations: Implications for the Future Role of Regional Organisations. In C. d. Coning, \& P. M. (Eds.), United Nations Peace Operations in a Changing Global Order. Palgrave Macmillan.

[7] Heally, S. (2011). Seeking peace and security in the Horn of Africa: the contribution of the Inter-Governmental Authority on Development. International Affairs, 87(1), 105-120. 
[8] Hegre, H., Hultman, L., \& Nygård, H. M. (2018). Evaluating the Conflict-Reducing Effect of UN Peacekeeping Operations. The Journal of Politics, 81(1), 215- 232.

[9] Henneberg, I., \& Stapel, S. (2021). Cooperation and Conflict at the Horn of Africa: A New Regional Bloc Betweeen Ethiopia, Eritrea and Somalia and its Consequences for Eastern Africa. Africa Spectrum, 55(3), 339-350.

[10] Hesse, B. J. (2016). Two Generations, Two Interventions in One of the World's Most-Failed States: The United States, Kenya and Ethiopia in Somalia. Journal of Asian and African Studies, 51(5), 573-593.

[11] Jansen, S. J. (2013). Al-Shabaab in Somalia. New York: Oxford University Press.

[12] Khadiagala, G. (2008). Eastern Africa: Security and the Legacy of Fragility. International Peace Institute.
[13] Lochery, E. (2012). Rendering Differences Visible: The Kenyan State and its Somali Citizens. African Affairs, 615

[14] Ploch, L., Blanchard, C. M., O'Rourke, R., Mason, R. C., \& King, R. O. (2011). Piracy Off the Horn of Africa. Congressional Research Services.

[15] Swan, J. (2007). U.S. Policy in the Horn of Africa . International Conference on African Development Archives.

[16] Wickstead, M. (2013, May 9). IGAD's Role in Stability and Diplomacy in the Horn of Africa . Chatham House.

[17] Witt, A. (2020). Taking Intervention Politics Seriously: Media Debates and the Contestation of African Regional Interventions 'from Below'. Journal of Intervention and Statebuilding, 271-288.

[18] Wondemagegnehu, D. Y., \& Kebede, D. G. (2017). AMISOM: Charting a New Course for African Union Peace Missions. African Security Review, 26(2), 199-219. 